\title{
ANALISIS TINGKAT LITERASI KEUANGAN TERHADAP PERILAKU KONSUMTIF PADA REMAJA SUMBAWA
}

\author{
Ezi Julian, Nova Adhitya Ananda ${ }^{2}$, Sri Andriani ${ }^{3}$ \\ Jurusan Manajemen Fakultas Ekonomi dan Bisnis Universitas Teknologi Sumbawa
}

\begin{abstract}
Financial literacy is closely related to financial management. Financial literacy is one of the important things for every individual, one of them for teenagers. Financial literacy for adolescents aims to enable teenagers to avoid financial problems, especially related to consumer behavior, indicators of financial management, namely (1) general financial management knowledge, (2) savings and loans, (3) insurance, (4) investment. Indicators of consumptive behavior are (1) advertising, (2) environment, (3) influence of friends.

This study aims to examine the level of financial literacy on the Sumbawa teenagers' consumptive behavior.This research is a quantitative research. Data collection methods were carried out by distributing questionnaires to 100 respondents, namely Sumbawa teenagers. The sampling technique uses purposive sampling. Data analysis used is logistic regression analysis. Based on the results of the study it can be concluded that there is a significant negative influence between the financial allocation of consumptive behavior. Where the higher financial literacy, consumer behavior will decrease.
\end{abstract}

Key Words: financial literation, consumptive behavior, and adolescents.

\begin{abstract}
ABSTRAK
Literasi keuangan sangat erat hubungannya dengan manajemen keuangan. Literasi keuangan merupakan salah satu hal penting bagi setiap individu, salah satunya bagi remaja. Literasi keuangan bagi remaja bertujuan agar remaja dapat terhindar dari suatu masalah keuangan terutama berkaitan dengan perilaku konsumtif, indikator dari manajemen keuangan yaitu (1) pengetahuan umum pengelolaan keuangan, (2) tabungan dan pinjaman, (3) asuransi, (4) investasi. Indikator dari perilaku konsumtif yaitu (1) iklan, (2) lingkungan, (3) pengaruh teman.
\end{abstract}

Penelitian ini bertujuan untuk menguji tingkat literasi keuangan terhadap perilaku konsumtif remaja Sumbawa. Penelitian ini merupakan penelitian Kuantitatif. Metode pengumpulan data dilakukan dengan membagikan kuesioner pada 100 responden yaitu remaja Sumbawa. Teknik pengambilan sampel menggunakan purposive sampling. Analisis data yang digunakan yaitu analisis regresi Logistik. Berdasarkan hasil penelitian dapat disimpulkan bahwa terdapat pengaruh negatif signifikan antaraliterasi keuangan terhadap perilaku konsumtif. Dimana semakin tinggi literasi keuangan maka perilaku konsumtif akan menurun.

Kata Kunci: literasi keuangan, perilaku konsumtif, dan remaja.

\section{PENDAHULUAN}

\subsection{Latar Belakang}

Literasi keuangan sangat erat hubungannnya dengan manajemen keuangan. Dimana semakin baik literasi keuangan maka manajemen keuangan juga semakin baik. Literasi keuangan merupakan pengetahuan, perencanaan dan pengelolaan keuangan pribadi ataupun keluarga yang dimana literasi keuangan ini merupakan salah satu perilaku ekonomi masyarakat yang terus dijalani bertahun-tahun baik disadari ataupun tidak disadari (Siahaan, 2013). Menurut Ulfatun dkk (2016) literasi keuangan merupakan suatu hal yang seharusnya menjadi kebutuhan dasar tiap-tiap individu atau masyarakat dalam mengelola keuangan. Hal ini dikarenakan apabila terjadi kesalahan dalam pengelolaan keuangan akan menimbulkan masalah dalam keuangan, contoh yang paling konkret adalah terjadinya kesulitan ekonomi.

Dari hal tersebut maka literasi keuangan dapat dimulai dari lingkungan terkecil seperti keluarga dan dapat dilakukan sedini mungkin. Di dalam lingkungan keluarga, tingkat literasi keuangan ditentukan oleh peran orang tua dalam memberikan dukungan berupa pendidikan keuangan dalam keluarga (Widayati, 2012). Namun hal ini tidak menutup kemungkinan diajarkan ketika remaja, karena masa remaja merupakan masa dimana seseorang tertarik untuk mempelajari hal-hal baru ( Indah, 2013). Remaja di Indonesia berusia 15-22 tahun kebanyakan masih menempuh jalur pendidikan formal disatu pendidikan SMA maupun Universitas tertentu.

Remaja pada masa SMA yang mengambil jurusan IPS telah menerima pendidikan keuangan seperti ekonomi, perilaku konsumen dan produsen, pendapatan nasional, konsumsi dan investasi, uang dan perbankan, ketenagakerjaan dan sebagainya ( Imawati dkk, 2013). Namun pembelajaran yang diterima di SMA belum dapat diaplikasikan secara maksimal sehingga perilaku konsumtif masih dilakukan oleh para siswa. Pada tingkat Universitas, remaja umumnya memiliki kebebasan yang lebih besar untuk membuat keputusan pribadi dalam hal keuangan (Widayati, 2013). Margaretha dan Pambudhi (2015) berpendapat bahwa mahasiswa harus bisa 
mandiri dalam mengatur keuangannya dengan baik dan dapat mempertanggung jawabkan atas keputusan pengelolaan keuangan yang diambil. Banyak mahasiswa yang belajar dari trial and error, namun hal itu belum mampu menjadikan mahasiswa menjadi pelaku ekonomi yang cerdas dalam kehidupan saaat ini (Widayati, 2012). Banyak penelitian dilakukan pada mahasiswa dan hasilnya menunjukkan bahwa pengetahuan tentang literasi keuangan dikalangan mahasiswa masih sangat rendah, mengindikasi literasi keuangan rendah walaupun melalui pendidikan sekolah sudah diberikan materi-materi perkuliahan yang berkaitan dengan aspek-aspek dalam literasi keuangan (Mendari Dan Kewal ,2015).

Ketidaktahuan mahasiswa akan literasi keuangan serta sikap konsumtif dan boros mahasiswa juga merupakan masalah yang dihadapi oleh mereka. Remaja gemar mencoba sesuatu yang baru karena rasa penasarannya yang tinggi, disamping lebih berorientasi pada lingkungan pergaulan yang membuatnya menjadi berperilaku boros. Pola konsumsi yang berlebihan cenderung timbul karena perilakuperilaku yang selalu mengikuti trend dan tuntutan sosial. Hal ini dapat dikarenakan proses pembelajaran keuangan yang kurang optimal dari remaja tersebut, yang tentu harus diuji kebenarannya pada penelitian selanjutnya (Imawati dkk, 2013).

Ulfi dkk, (2017) yang menyatakan bahwa kelompok usia remaja adalah salah satu pasar yang potensial bagi produsen. Hal tersebut terjadi karena pola konsumtif seseorang terbentuk pada usia remaja. Pada masa remaja pola konsumtif mulai terbentuk karena remaja cendrung mudah terbujuk rayuan iklan, mudah terpengaruh teman dan cendrung boros (Ulfi dkk, 2017). Anggapan bahwa remaja sudah dewasa, mandiri dan dapat melakukan segala sesuatu dengan sendiri itulah yang semakin mendorong remaja menjadi semakin konsumtif (Kusumaningtyas \& Sakti, 2017). Perilaku konsumtif yang dimaksud disini merupakan suatu perilaku membeli yang tidak lagi didasarkan pada pertimbangan yang rasional melainkan karena adanya keinginan yang sudah mencapai taraf yang tidak rasional lagi (Imawati dkk, 2013).

\subsection{Rumusan Masalah}

Berdasarkan latar belakang di atas, maka rumusan masalah dalam penelitian ini adalah sebagai berikut:

a. Bagaimana tingkat pemahaman literasi keuangan pada remaja?

b. Bagaimana pengaruh literasi keuangan terhadap perilaku konsumtif remaja?

\section{STUDI LITERATUR}

\subsection{Manajemen Keuangan}

Keuangan merupakan aspek penting yang melekat dalam kehidupan masyarakat luas. Pengetahuan keuangan yang dimiliki dapat membantu individu dalam menentukan keputusan-keputusan dalam menentukan produk-produk keuangan yang dapat mengoptimalkan keputusan keuangannya

\subsection{Literasi Keuangan}

Literasi keuangan adalah pengetahuan, perencanaan, dan pengelolaan keuangan pribadi atau keluarga yang merupakan salah satu perilaku ekonomi yang berkembang di masyarakat dengan sadar ataupun tidak sadar telah dijalani selama bertahun-tahun" (Siahaan, 2013). Literasi keuangan atau melek keuangan merupakan faktor penting bagi setiap orang dalam mengelola keuangan pribadinya. Kemampuan seseorang untuk membaca, menganalisis dan mengelola kondisi keuangan saat akan membuat suatu keputusan keuangan akan membuat seseorang terhindar dari masalah keuangan ( Rio dkk, 2014).

\subsection{Perilaku Konsumtif}

Perilaku konsumtif yang dilakukan oleh remaja ataupun orang dewasa pada saat ini merupakan suatu realita yang ada (Imawati dkk,2013). Perilaku konsumtif adalah suatu perilaku membeli yang tidak lagi didasarkan pada pertimbangan yang rasional melainkan karena adanya keinginan yang sudah mencapai taraf yang tidak rasional lagi (Rosyid, 1991). Sedangkan Margaretha \& Pambudhi (2015) menyatakan perilaku konsumtif adalah perilaku membeli tidak rasional dan membeli karena sebuah pengakuan.

\subsection{Remaja}

Remaja adalah suatu masa dalam perkembangan manusia yang merupakan masa transisi atau peralihan dari masa kanak-kanak ke masa dewasa yang ditandai dengan terjadinya perubahan cepat pada diri mereka baik fisik, seksual maupun psikis dan mereka berada dalam rentang umur 15 tahun sampai 22 tahun (Muzzakir, 2011).

\subsection{Kerangka Berpikir}

Dari deskripsi teori diatas dapat dikatakan bahwa literasi keuangan dapat mempengaruhi perilaku konsumtif pada remaja. Berikut penggambaran kerangka berpikir dari literasi keuangan pada remaja.

\begin{tabular}{|l|l|l|}
\hline $\begin{array}{l}\text { Literasi } \\
\text { Keuangan } \\
((\mathrm{X})\end{array}$ & $\stackrel{\text { Metode penelitian }}{\longrightarrow}$ & $\begin{array}{l}\text { Perilaku } \\
\text { Konsumtif(Y) }\end{array}$ \\
\hline
\end{tabular}

\section{METODE PENELITIAN}

Pendekatan yang digunakan dalam penelitian adalah pendekatan kuantitatif. Metode dalam penelitian ini menggunakan penelitian inferensial. Pendekatan kuantitatif 
lebih menekankan pada pengujian teori melalui pengukuran variable penelitian dengan angka dan melakukan analisis data dengan prosedur statistik. Dimana Populasi penelitian ini merupakan remaja sumbawa yang berumur sekitar antara 15 tahun sampai 22 tahun dan masih menempuh pendidikan baik di SMA maupun di Universitas.sampel berjumlah 100 sampel dan diambil dengan teknik purposive sampling. Data dikumpulkan dengan metode kuesioner dan dokumentasi. Analisis data menggunakan regresi logistik. Skala yang digunakan yaitu skala ordinal. Butir pertanyaan dari kuesioner diuji tingkat validitas dan reliabilitas setelah itu baru diuji kelayakan modelnya menggunakan Uji Hosmer dan Lemeshow, Uji Wald, Uji Odds Rasio Dan Uji Regresi Logistik

\section{PEMBAHASAN HASIL PENELITIAN}

\section{Gambaran umum Perilaku konsumtif}

Peraku konsumtif merupakan perilaku membeli barang yang tidak sesuai dengan kebutuhan melainkan hanya semata-mata karena keinginan saja. Perilaku konsumtif ini mulai muncul pada masa remaja karena pada masa remaja, remaja cenderung mencoba hal baru dan mudah terpengaruh oleh teman.

1. Tingkat literasi keuangan remaja sumbawa

\begin{tabular}{|l|c|c|c|c|}
\hline Pendidikan & $\begin{array}{l}\text { Literasi } \\
\text { Keuangan } \\
\text { Tinggi }\end{array}$ & Persentase & $\begin{array}{l}\text { Literasi } \\
\text { Keuangan } \\
\text { Rendah }\end{array}$ & Persentase \\
\hline SMA & 38 & $76 \%$ & 12 & $24 \%$ \\
\hline Universitas & 44 & $88 \%$ & 6 & $12 \%$ \\
\hline Jumlah & 82 & & 18 & \\
\hline
\end{tabular}

Sumber data: excel

Responden dilihat dari segi pendidikan, Responden SMA dan Universitas memiliki tingkat literasi keuangan yang berbeda dimana persentase tingkat literasi keuangan pada SMA sebesar $76 \%$ sedangkan pada tingkat Universitas yang memiliki literasi keuangan yang tinggi sebesar $88 \%$. Artinya remaja yang ditingkat Universitas memiliki tingkat literasi lebih tinggi dibandingkan tingkt SMA. Remaja pada tingkap Universitas telah lebih banyak belajar tentang pengelolaan keuangan serta konsep-konsep tentang keuangan yang lebih banyak dibandingkan dengan remaja di tingkat SMA, sehingga remaja pada tingkat Universitas dapat mengatur dan mengambil keputusan yang lebih tepat dalam pengelolaan keuangan seperti kapan waktu yang tepat dalam berinvestasi dan menabung. Pada tingkat SMA remaja hanya di ajarkan konsep mengenai literasi keuangan sedangkan pada tingkat

Universitas remaja mulai belajar lebih dalam tentang literasi keuangan seperti belajar tentang saham dan praktek langsung cara berinvestasi.

2. Pengaruh literasi keuangan terhadap perilaku konsumtif pada remaja Sumbawa

1. Uji Hosmer dan Lemeshow Tabel Hosmer and Lemeshow
Hosmer and Lemeshow Test

\begin{tabular}{|l|r|r|r|}
\hline Step & Chi-square & Df & Sig. \\
\hline 1 & 9.573 & & 7 \\
\hline
\end{tabular}

Tabel tersebut menunjukkan bahwa besar nilai statistik pada hosmer and lemeshow test yaitu sebesar 9.573 dengan tingkat probabilitas 0.214 yang nilainya lebih besar dari 0.05 , maka H0 diterima. Hal ini menyatakan bahwa model yang dihipotesiskan fit dengan data (tidak ada perbedaan antara model dengan data sehingga model dapat dikatakan fit) sehingga data layak diujikan dalam regresi logistik.

2. Uji Wald

Tabel Hasil Uji Wald

Variables in the Equation

\begin{tabular}{|l|r|r|r|r|}
\hline & \multicolumn{1}{|c|}{ B } & Wald & \multicolumn{1}{c|}{ Sig. } & Exp(B) \\
\hline SLiterasi Keuangan & -.205 & 6.605 & .010 & .814 \\
$\mathrm{t}$ Constant & & & & \\
$\mathrm{k}$ & 1.410 & 2.743 & .098 & 4.096 \\
\hline & & & & \\
\hline
\end{tabular}

a. Variable(s) entered on

step 1: jmlh.

Dari tabel diperoleh nilai p untuk uji wald sebesar 6.605 dengan nili sig. 0.010 . Karena nilai p lebih kecil daripada 0,05 maka hipotesis nol ditolak. Dari hasil tersebut maka dapat disimpulkan bahwa terdapat hubungan antara literasi keuangan dengan perilaku konsumtif, dimana semakin tinggi tingkat literasi keuangan remaja maka perilaku konsumtifnya semakin rendah.

3. Uji OR

Tabel Hasil Uji OR

Variables in the Equation

\begin{tabular}{|l|r|r|r|r|}
\hline & \multicolumn{1}{|c|}{ B } & \multicolumn{1}{|c|}{ Wald } & \multicolumn{1}{c|}{ Sig. } & Exp(B) \\
\hline $\begin{array}{l}\text { S Literasi Keuangan } \\
\mathrm{t} \text { Constant }\end{array}$ & -.205 & 6.605 & .010 & .814 \\
$\mathrm{p}$ & & & & \\
1 & 1.410 & 2.743 & .098 & 4.096 \\
\hline $\mathrm{a}$ & & & & \\
\hline
\end{tabular}

a. Variable(s) entered on step

1: jmlh.

Tabel menunjukkan besarnya pengaruh nilai EXP (B) atau disebut juga ODDS Rasio (OR). Nilai OR 0.814, artinya oods remaja yang memiliki literasi keuangan dapat berperilaku konsumtif sebanyak 0.814 kali lipat dibandingkan dengan remaja yang tidak memiliki literasi keuangan. 
4. Uji Hipotesis

Tabel

Omnibus Tests of Model Coefficients

\begin{tabular}{|rl|r|r|r|}
\hline & & Chi-square & df & \multicolumn{1}{c|}{ Sig. } \\
\hline Step 1 & Step & 7.276 & 1 & .007 \\
& Block & 7.276 & 1 & .007 \\
& Model & 7.276 & 1 & .007 \\
\hline
\end{tabular}

Uji simultan dapat dilihat dimana jika nilai signifikan lebih kecil daripada 0.05 maka variabel bebas mempengaruhi variabel terikat. Nilai Chi-square sebesar 7.276 dengan signifikansi 0.007 . Hal ini menunjukkan bahwa variabel pada tabel lebih kecil dari 0.05 artinya literasi keuangan secara simultan berpengaruh positif terhadap perilaku konsumtif remaja.

\section{Variables in the Equation}

\begin{tabular}{|l|r|r|r|r|}
\hline & \multicolumn{1}{|c|}{$\mathrm{B}$} & \multicolumn{1}{|c|}{ Wald } & Sig. & Exp(B) \\
\hline S LiterasiKeuangan & -.205 & 6.605 & .010 & .814 \\
$\mathrm{t}$ Constant & & & & \\
$\mathrm{p}$ & 1.410 & 2.743 & .098 & 4.096 \\
1 & & & & \\
\hline
\end{tabular}

a. Variable(s) entered on step

\section{1: imlh.}

Hasil dari tabel variabel in the equation menunjukkan bahwa literasi keuangan berpengaruh signifikan terhadap perilaku konsumtif remaja Sumbawa. Artinya ketika literasi keuangan tinggi maka perilaku konsumtifnya rendah. Berdasarkan dari hasil pengelolaan data yang telah dilakukan dapat dilihat bahwa variabel literasi keuangan memiliki koefisien sebesar (-0.205) dengan tingkat signifikansi sebesar 0.010 ,lebih rendah dari 0.05 sehingga hipotesis diterima. Artinya setiap literasi keuangan mengalami satu kenaikkan maka diikuti dengan turunya perilaku konsumtif sebesar (-0.205). Dimana tanda minus () pada variabel literasi keuangan mengandung arti bahwa literasi keuangan berpengaruh negatif signifikan terhadap perilaku konsumtif. Hal ini mengartikan bahwa semakin tinggi tingkat literasi keuangan remaja maka perilaku konsumtif remaja semakin rendah. Penelitian ini sejalan dengan penelitian Imawati dkk (2013).

\section{Pembahasan Penelitian}

Setelah melakukan analisis data maka tahap selanjutnya adalah memaparkan hasil penelitian yang berdasarkan teori-teori yang relevan yang telah dilakukan oleh peneliti terdahulu. Penelitian ini berfokus pada analisis literasi keuangan terhadap perilaku konsumtif remaja Sumbawa. Hasil pengujian yang telah dilakukan di atas menunjukkan bahwa :

1. Tingkat Literasi Keuangan Remaja Sumbawa
Berdasarkan hasil pengujian statistik deskriptif menunjukkan bahwa tingkat literasi keuangan remaja Sumbawa tinggi. Literasi keuangan dikatakan tinggi apabila tingkat pengetahuan literasinya itu diatas $50 \%$ dan dikatakan rendah apabila dibawah 50\%. Sehingga literasi keuangan remaja Sumbawa dapat dikatakan tinggi sebesar $80 \%$, artinya remaja sudah memiliki pengetahuan dan cara pengelolaan keuangan yang baik. Tingginya literasi keuangan pada remaja Sumbawa dikarenakan mereka sudah memahami aspek-aspek dari literasi keuangan seperti pengetahuan umum keuangan pribadi, tabungan dan pinjaman, asuransi dan investasi. Pemahaman mengenai aspek literasi keuangan membuat remaja memiliki keputusan keuangan yang lebih tepat dibandingkan dengan remaja yang kurang literasi keuangannya.

Tingkat pendidikan juga mempengaruhi terhadap literasi keuangannya, tingkat literai keuangan di tingkata SMA dan Universitas berbeda. Hal ini sejalan dengan penelitian Margaretha dan Sari (2015) menemukan bahwa tingkat literasi keuangan berbeda antara lulusan pasca-sarjana,sarjana, atau hanya tingkat SMA.

2. Pengaruh Tingkat Literasi Keuangan Terhadap Perilaku Konsumtif Remaja

Berdasarkan hasil pengujian regresi logistik tinggi rendahnya literasi keuangan remaja dapat mempengaruhi perilaku konsumtif remaja tersebut. Semakin tinggi literasi keuangana remaja maka semakin rendah perilaku konsumtifnya. Hal ini terjadi karena remaja mengetahui bagaimana cara pengelolaan keuangan yang baik sehingga remaja dapat mengelola keuangan dengan cermat sehingga terhindar dari perilaku konsumtif. Ketika literasi keuangan tinggi maka akan menjadikan remaja sebagi konsumen yang cerdas dalam membeli barang dengan melihat manfaat dan kerugiannya.

Hasil penelitian ini sejalan dengan penelitian Rasyid (2012) dan penelitian Imawati dkk (2013) yang menyatakan bahwa ketika literasi keuangan tinggi maka perilaku konsumtif akan menurut. Literasi keuangan akan membuat seseorang memiliki pengelolaan keuangan yang baik, keuangan yang baik akan mempengaruhi perilaku remaja agar tidak berperilaku konsumtif. Remaja yang memiliki literasi keuangan yang tinggi akan mempertimbangkan membeli atau menggunakan sesuatu dengan melihat manfaat dan kerugiannya sehingga menjadikan remaja sebagai konsumen yang cerdas dalam pengelolaan keuangannya.

\section{Simpulan}

Berdasarkan hasil analisis penelitian dari data yang telah dilakukan dalam penelitian ini , maka diperoleh simpulan sebagai berikut : 
1. Remaja Sumbawa memiliki tingkat literasi keuangan yang tinggi yaitu sebesar $80 \%$.

2. Tingkat literasi keuangan memengaruhi perilaku konsumtif. Ketika literasi keuangan tinggi maka perilaku konsumtif menjadi rendah. Remaja yang memiliki literasi keuangan yang tinggi akan mempertimbangkan membeli atau menggunakan sesuatu dengan melihat manfaat dan kerugiannya sehingga menjadikan remaja sebagai konsumen yang cerdas dalam pengelolaan keuangannya.

\section{Saran}

Berdasarkan hasil analilsis dari data yang telah dilakukan dalam penelitian ini, maka saran-saran yang dapat diberikan sebagai berkut :

a. Bagi Peneliti Selanjutnya

1. Karena pada penelitian ini hanya menggunakan satu variabel saja. Diharapkan pada penelitian selanjutnya dapat menggunakan variabel yang lebih variatif misalnya seperti variabel gaya hidup.

2. Diharapkan untuk penelitian selanjutnya dapat menambah jumlah sampel.

3. Penelitian ini menggunakan regresi non linier, alat analisis regresi logistik. Diharapkam pada penelitian selanjutnya dapat menggunakan alat analisis lain selain regresi logistik non linier.

b. Bagi Tempat Akademis

Bagi pihak akademis lebih memahami manajemen keuangan mengenai pengetahuan keuangan dan perilaku konsumtif.

\section{DAFTAR PUSTAKA}

Basuki, Agus Tri. Regresi Logistik Binner. Yogyakarta: Bahan Ajar Ekonometrika.

Imawati, indah, Susilaningsih, \& Elvia Ivada. 2013. Pengaruh Financial Literacy Terhadap

Perilaku Konsumtif Remaja pada Program IPS SMA Negeri 1 Surakarta Tahun Ajaran 2012/2013. Surakarta: Jupe UNS. VOL 2.

Kusumaningtyas, Indarti \& Drs. Norida Canda Sakti. 2017. Pengaruh Literasi

Keuangan Dan Gaya Hidup Terhadap Perilaku Konsumtif Siswa Kelas XIII IPS di SMA NEGERI 1 TAMAN SIDOARJO. Surabaya: jurnal pendidikan ekonomi. Vol 5.

Margaretha, Farah \& Sari Siti May. 2015. Faktor Penentu Tingkat Literasi Keuangan Para
Pengguna Kartu Kredit di Indonesia: Jakarta. Jurnal akuntansi \& investasi. Vol 16.

Mendari, Anastasia Sri \& Suramaya Suci Kewal. 2013. Tingkat Literasi Keuangan Di Kalangan Mahasiswa STIE MUSI. Palembang: Jurnal Econimia. Vol 9.

Muzakkir. 2011. Pendidikan remaja. Makassar: Jurnal AlHikmah. Vol XII.

Rasyid, Rosyeni. 2012. Analisis Tingkat Literasi Keuangan Mahasiswa Program Studi

Manajemen Fakultas Ekonomi Universitas Negeri Padang. Padang: Kajian manajemen bisnis. Vol 1.

Rio, Rita, Maria \& Benaya Chrisma Adiputra Pesudo. 2014. Apakah Mahasiswa Sudah Melek

Keuangan?. Salatiga: Dinamika Akuntansi, Keuangan dan Perbankan. Vol 3.

Ulfi, Dina Shofa, Siswandari \& Dini Octoriav. 2017. Hubungan Literasi Keuangan dan Perilaku Sebaya Dengan Kebiasaan Menabung. Suakarta: Jurnal Tata Arta.

Widayati, Irin. 2012. Faktor-Faktor Yang Mempengaruhi Literasi Financial Mahasiswa Fakultas

Ekonomi dan Bisnis Universitas Brawijaya. Jurnal Akuntansi dan pendidikan. Vol 1. 